\title{
Effects Of Pigeon PEA (Cajanus Cajan) Consumption to Decrease Blood Pressure on Elderly Hypertension in the Region of Barana Health Center of Jeneponto
}

\author{
Muhammad Khidri Alwi ${ }^{1}$, Sri Julyani ${ }^{2}$, \\ Yusriani, Nurfardiansyah Burhanuddin' ${ }^{1}$, Sulfiana S. ${ }^{1}$, Burhanuddin Bahar ${ }^{3}$ \\ ${ }^{1}$ Faculty of Public Health, Universitas Muslim Indonesia, 90231, ${ }^{2}$ Faculty of Medicine, Universitas Muslim \\ Indonesia, ${ }^{3}$ Faculty of Public Healthc Universitas Hasanuddin
}

\begin{abstract}
Hypertension is a high-risk condition that causes of deaths, stroke, and coronary heart disease. This study aims to determinethe effect of giving pigeon pea (Cajanus cajan) baruasa on systolic and diastolic blood pressure of elderly with hypertension.

The research is quasy experimental design with pre-post test group. A total of 36 elderly people with hypertension were divided into intervention group and control group by random sampling. Data were analyzed using Mann-Whitney and Wilcoxon with 95\% confidence level.

The results of this study indicate that: There is an effect giving pigeon pea (Cajanus cajan) baruasa on the systolic blood pressure of elderly with hypertension $(p=0.001<0.05)$; (4) There is an effect giving pigeon pea (Cajanus cajan) baruasa to the diastolic blood pressure of elderly with hypertension $(p=0.001<0.05)$.

The conclusion of this study that consumption of pigeon pea (Cajanus cajan) baruasa can reduce of blood pressure on elderly hypertensive in Jeneponto district.

The suggestions for researcher presumably can further investigate the influence of pigeon pea baruasa on blood pressure in elderly man with hypertension and long storage time (expiration date) of pigeon pea baurasa.
\end{abstract}

Keywords: Cajanus cajan, Blood Pressure, Elderly, Baruasa.

\section{Introduction}

Aging is a process of change that is thorough and spontaneous that starts from cooked-childhood, puberty, adulthood young and then declined in the mid to advanced age. The increase in the population of advanced age (elderly) has become the focus of which attracts attention in countries growing because of the numbers of hope alive that maki increase. ${ }^{1}$

In 2050 it is estimated that around $75 \%$ of the elderly suffer from degenerative diseases with conditions that cannot be active freely. ${ }^{2}$ One of the most common chronic diseases affecting the elderly is hypertensionwhich is "the silent killer" Because of its asymptomatic nature and after several years it causes fatal stroke or heart disease. ${ }^{3,4}$
Chinnakali et al. reported that hypertension is a high-risk condition that accounts for $51 \%$ of deaths from stroke and $45 \%$ of coronary heart disease. Cardiovascular disease is responsible for nearly 17 million deaths worldwide, with hypertension being the main contributor to more than half of these cases, which is about $55 \%$. 5,6

Hypertension is associated with an increased risk of coronary heart disease, stroke, peripheral vascular disease, cognitive impairment, kidney problems, and vision problems. ${ }^{7}$ Also, $17-21 \%$ of the $60 \%$ of hypertension sufferers end in stroke, especially in the elderly. ${ }^{8,9}$

In Indonesia, $13 \%$ of deaths among elderly people in 2002 suffered from hypertension (57.4\%). This 
proportion is bigger than the previous study in 2001, namely $50 \%$. The increasing prevalence of hypertension is considered to be a worrying problem so that public awareness and awareness in managing hypertension must be increased.$^{10}$

The results of the Basic Health Research conducted by interview showed that the national tendency of hypertension had increased, namely by $7.6 \%$ in 2007 , increasing to $9.5 \%$ in 2013 . Furthermore, South Sulawesi province also shows a trend of increasing hypertension which is even more rapid than nationally, namely around $5 \%$ in 2007 to around $10.5 \%$ in $2013 .^{2}$

In Jeneponto Regency, the number of cases of hypertension throughout 2014 was 21,703 cases. ${ }^{11}$ One of the health centers with the highest number of hypertension sufferers in the Jeneponto Regency is at Barana Health Center. Based on data obtained from PuskesmasBarana, it shows that the number of hypertension cases was quite high in 2015 , namely $12.40 \%$ in the group of women $\geq 18$ years. ${ }^{12}$ This shows that the proportion of the incidence of hypertension in the women group in the working area of the Barana Health Center is higher than the national proportion $(9.5 \%)$ and even higher than the proportion at the South Sulawesi level of $10.5 \%{ }^{2}$

Pigeon pea are one of the most abundant local foods in the Jeneponto district. Pigeon pea can be processed into flour which can be used as an application in food ingredients. ${ }^{13}$ Mollik reports that gude bean (Cajanus cajan) is one of the plants that have the potential to treat hypertension. Pigeon pea (Cajanus cajan) contain minerals such as potassium, magnesium, calcium and are very low in sodium. ${ }^{14} \mathrm{~A}$ low sodium diet is one of the treatments for hypertension. ${ }^{15}$ Pigeon pea (Cajanus cajan) are also rich in antioxidants which have been shown to reduce blood pressure. ${ }^{16}$ Therefore, researchers are interested in conducting research related to the effect of gudean (Cajanus cajan) consumption on blood pressure reduction in hypertensive elderly in the working area of Barana Health Center, Jeneponto Regency. ${ }^{16}$

The general objective of this study was to determine the effect of gudean (Cajanus cajan) consumption on blood pressure reduction in hypertensive elderly in the working area of Barana Health Center, Jeneponto Regency.

\section{Materials and Method}

This study is a quasi-experimental study with prepost test design. In this study, the treatment variables were giving Pigeon Pea s (Cajanus cajan) in the form of baruasa cake in the intervention group and giving ordinary new cakes to the comparison group, while the dependent variable was the blood pressure level (systolic and diastolic) of elderly women in the working area of the Barana District Health Center. Jeneponto.

Blood pressure measurements and interventions were carried out in the work area of the Barana Community Health Center, Jeneponto district, from January to February 2017. Gudebaruasa cake is given as much as 4 pieces@25 g a day for 1 month. The number of elderly people who were sampled in this study was 36 elderly who were divided into two groups (intervention group and comparison group).

Blood pressure data were obtained from the results of measuring blood pressure in the elderly using a sphygmomanometer.To determine the effect of giving pigeon pea taste and ordinary taste on systolic blood pressure in the elderly before and after the intervention, the Wilcoxon analysis was used. Meanwhile, the hypothesis test to determine the effect of giving a new taste of gudean nuts and ordinary taste on the blood pressure of the elderly in the intervention group and comparison group used Mann Whitney analysis. Likewise, to compare the consumption pattern of the elderly in the intervention group and the comparison group, the Mann Whitney test was used.

Data analysis was performed using SPSS with a confidence degree of $95 \%$, so that if $p<0.05$, it can be concluded that there is a significant difference/effect.

\section{Results}

The characteristics of elderly hypertension include age, education, occupation, and marital status. 
Table 1. Distribution of Elderly Hypertension Based on Characteristics at Work Area of Barana Health Center, Jeneponto Regency

\begin{tabular}{|c|c|c|c|c|c|}
\hline \multirow{3}{*}{ Characteristics } & \multirow{3}{*}{ Category } & \multicolumn{4}{|c|}{ Group } \\
\hline & & \multicolumn{2}{|c|}{ Intervention } & \multicolumn{2}{|c|}{ Comparison } \\
\hline & & n (18) & $\%$ & n (18) & $\%$ \\
\hline \multirow{2}{*}{ Age } & $60-64$ years & 9 & 50 & 9 & 50 \\
\hline & $65-74$ years & 9 & 50 & 9 & 50 \\
\hline \multirow{4}{*}{ Education } & No school & 8 & 44.4 & 0 & 0 \\
\hline & SD & 4 & 22.2 & 0 & 0 \\
\hline & Junior High & 4 & 22.2 & 3 & 16.7 \\
\hline & High school & 2 & 11.1 & 15 & 83.3 \\
\hline \multirow{2}{*}{ Profession } & IRT & 13 & 72.2 & 16 & 88.9 \\
\hline & Farmer & 5 & 27.8 & 2 & 11.1 \\
\hline \multirow{3}{*}{ Marital status } & Not Married & 2 & 11.1 & 0 & 0 \\
\hline & Married & 10 & 55.6 & 15 & 83.3 \\
\hline & Widow & 6 & 33.3 & 3 & 16.7 \\
\hline
\end{tabular}

Source: Primary Data, 2017.

Table 1 shows that there is the same number of elderly aged 60-64 years and 65-74 years, both in the intervention group and the comparison group (50\%). Based on the latest education of the elderly, there were more elderly who did not attend school in the intervention group, namely as many as 8 elderly (44.4\%). In the comparison group, there were more elderly with senior high school education, namely 15 elderly (83.3\%).Based on occupation, there were more elderly who worked as IRT, namely 13 elderly (72.2\%) in the intervention group and 16 elderly $(88.9 \%)$ in the comparison group. Based on marital status, no one was unmarried in the comparison group ( $0 \%$ ), and there were 2 unmarried elderly $(11.1 \%)$ in the intervention group.

The condition of elderly hypertension is divided into 3 categories, namely pre-hypertension, grade 1 hypertension, and grade 2 hypertension.

Table 2. Distribution of Elderly Based on Degree of Hypertension at Work Area of Barana Health Center, Jeneponto Regency

\begin{tabular}{|c|c|c|c|c|c|c|c|c|c|}
\hline \multirow{4}{*}{$\begin{array}{l}\text { Blood } \\
\text { pressure }\end{array}$} & \multirow{4}{*}{ Level } & \multicolumn{8}{|c|}{ Group } \\
\hline & & \multicolumn{4}{|c|}{ Intervention } & \multicolumn{4}{|c|}{ Comparison } \\
\hline & & \multicolumn{2}{|c|}{ Pre } & \multicolumn{2}{|c|}{ Post } & \multicolumn{2}{|c|}{ Pre } & \multicolumn{2}{|c|}{ Post } \\
\hline & & n (18) & $\%$ & n (18) & $\%$ & n (18) & $\%$ & n (18) & $\%$ \\
\hline \multirow{3}{*}{ Systolic } & Pre Hypertension & 0 & 0 & 5 & 27.8 & 0 & 0 & 0 & 0 \\
\hline & $140-159 *$ & 6 & 33.3 & 8 & 44.4 & 12 & 66.7 & 15 & 83.3 \\
\hline & $\geq 160 \#$ & 12 & 66.7 & 5 & 27.8 & 6 & 33.3 & 3 & 16.7 \\
\hline \multirow{3}{*}{ Diastolic } & Pre Hypertension & 1 & 5,6 & 8 & 44.4 & 0 & 0 & 0 & 0 \\
\hline & $90-99 *$ & 1 & 5,6 & 5 & 27.8 & 0 & 0 & 3 & 16.7 \\
\hline & $\geq 100 \#$ & 16 & 88.9 & 5 & 27.8 & 18 & 100 & 15 & 83.3 \\
\hline
\end{tabular}

Source: Primary Data, 2017.

Ket. * = Hypertension Grade 1

\# = Hypertension Grade 2 
Table 2 shows that based on systolic blood pressure, the elderly in the intervention group are mostly in the category of grade 2 hypertension, namely 12 people $(66.7 \%)$ at the time before the intervention. Meanwhile, after the intervention, more elderly were in the 1st-degree hypertension category, namely as many as 8 people (44.4\%). Meanwhile, the elderly in the comparison group were mostly in the grade 2 hypertension category, namely 12 people $(66.7 \%)$ before the intervention. After the intervention, more elderly remained in the 1st-degree hypertension category, namely 15 people $(83.3 \%)$.
Also, based on the diastolic blood pressure of the elderly in the intervention group, there were more than 16 people in the category of grade 2 hypertension $(88.9 \%)$ before the intervention. Meanwhile, after the intervention, more elderly were in the prehypertension category, namely as many as 8 people (44.4\%). Meanwhile, all elderly in the comparison group were in the category of hypertension grade $2(1007 \%)$ at the time before the intervention. After the intervention, there were 3 elderly (16.7\%) who switched to the category of grade 1 hypertension (table 2).

Table 3 . Distribution of Elderly Hypertension according to Results Systolic Blood Pressure Measurement Pre and Post Treatment at PuskesmasBarana, Jeneponto Regency

\begin{tabular}{|l|c|c|c|c|c|c|c|}
\hline \multirow{2}{*}{ Group } & \multicolumn{9}{|c|}{ Systolic Blood Pressure } & \multicolumn{3}{c|}{ Post } \\
\cline { 2 - 9 } & \multicolumn{3}{|c}{ Pre } & SD & Mean & \pm & SD \\
\cline { 2 - 9 } & Mean & \pm & 14.33 & 145.00 & \pm & 20.65 & 0.001 \\
\hline Intervention & 160.56 & \pm & 9.37 & 151.11 & \pm & 6.76 & 0.705 \\
\hline Comparison & 150.56 & \pm & &
\end{tabular}

Source: Primary Data, 2017. $\mathrm{n}=18$

Table 3 shows that based on the results of the Wilcoxon test, there is a significant effect on changes in systolic blood pressure before and after treatment in the intervention group $(\mathrm{p}=0.001<0.05)$ with the provision of gudea nut taste. Meanwhile, the comparison group showed an insignificant effect $(p=0.705>0.05)$ after treatment. It can also be seen that there was a decrease in the mean systolic blood pressure in the intervention group, namely $160.56 \mathrm{mmHg}$ to $145.00 \mathrm{mmHg}$ after treatment. Meanwhile, in the comparison group, the elderly actually experienced an increase in the mean systolic blood pressure, namely $150.56 \mathrm{mmHg}$ to 151.11 $\mathrm{mmHg}$ after treatment.

Table 4. Distribution of Elderly Hypertension according to Results Diastolic Blood Pressure Measurement Pre and Post Treatment at Puskesmas Barana, Jeneponto Regency

\begin{tabular}{|c|c|c|c|c|c|c|c|}
\hline \multirow{3}{*}{ Group } & \multicolumn{6}{|c|}{ Diastolic Blood Pressure } & \multirow{3}{*}{$\mathbf{P}$} \\
\hline & \multicolumn{3}{|c|}{ Pre } & \multicolumn{3}{|c|}{ Post } & \\
\hline & Mean & \pm & SD & Mean & \pm & SD & \\
\hline Intervention & 100.56 & \pm & 8.72 & 88.33 & \pm & 8.57 & 0.001 \\
\hline Comparison & 100.00 & \pm & 0.00 & 101.11 & \pm & 7.58 & 0.527 \\
\hline
\end{tabular}

Source: Primary Data, 2017. $\mathrm{n}=18$

Table 4 shows that based on the results of the Wilcoxon test, there is a significant effect on changes in diastolic blood pressure before and after treatment in the intervention group $(\mathrm{p}=0.001<0.05)$ with the provision of gudea nut taste. Meanwhile, in the comparison group, it was shown that the administration of ordinary basics had no significant effect on diastolic blood pressure in elderly hypertensive people $(\mathrm{p}=0.527>0.05)$. 
It can also be seen that there was a decrease in the mean diastolic blood pressure in the intervention group, namely $100.56 \mathrm{mmHg}$ to $88.33 \mathrm{mmHg}$ after treatment. Meanwhile, in the comparison group, the elderly experienced an increase in the mean diastolic blood pressure, from $100.00 \mathrm{mmHg}$ to $101.11 \mathrm{mmHg}$ after treatment (Table 4).

Table 5. Distribution of Elderly Hypertension Based on Blood Pressure Measurement Results in the
Intervention Group and the Comparison Group After Treatment at the Work Area

Barana Health Center, Jeneponto Regency:

\begin{tabular}{|l|c|c|c|c|c|c|c|}
\hline \multirow{3}{*}{ Blood pressure } & \multicolumn{5}{|c|}{ Group } & \multirow{2}{*}{ P } \\
\cline { 2 - 7 } & \multicolumn{3}{|c|}{ Intervention } & \multicolumn{3}{c|}{ Comparison } & \\
\cline { 2 - 8 } & Mean & \pm & SD & Mean & \pm & SD & \\
\hline Systolic & 145.00 & \pm & 20.65 & 151.11 & \pm & 6.76 & 0.077 \\
\hline Diastolic & 88.33 & \pm & 6.76 & 101.11 & \pm & 7.58 & 0,000 \\
\hline
\end{tabular}

Source: Primary Data, 2017.

$\mathrm{n}=18$

Table 5 shows that based on the results of the MannWhitney test, there is no significant difference in systolic blood pressure between the intervention group and the comparison group with $\mathrm{p}=0.077>0.05$. Meanwhile, there was a significant difference in diastolic blood pressure between the intervention group and the comparison group with $\mathrm{p}=0.000<0.05$.

\section{Discussion}

Increasing age is closely related to the emergence of hypertensive conditions. This is influenced by the occurrence of arteriosclerotic wear of the main arteries, especially the aorta, and reduced flexibility. The hardening of these arteries with time will become stiffer and stiffer until the arteries and aorta lose their adaptability. Inelastic walls can no longer maintain the smooth flow of blood out of the heart, thus affecting systolic and diastolic blood pressure. ${ }^{17}$

Some several metabolic changes and effects increase blood pressure including insulin resistance, increased oxidative stress, increased formation of advanced glycation end products (AGEs), decreased nitric oxide (NO) bioavailability, altered the renin-angiotensin system (RAS) function, and reduced-sodium excretion. in the kidneys. These changes can cause endothelial dysfunction due to an increase in cytosol-free calcium vascular, and peripheral vascular resistance which results in hypertensive conditions. ${ }^{17}$

In this study, elderly women aged 60-74 years.
Elderly women are one who is at high risk of developing hypertension. After entering menopause, the prevalence of hypertension in women is higher than in men. ${ }^{18}$ One of the mechanisms for high blood pressure in elderly women is menopause itself. During menopause, there is an increase in plasma renin activity which activates the renin-angiotensin system (RAS). ${ }^{19}$ The genetic component of the RAS contributes to certain renin gene polymorphisms associated with hypertension in women aged 40 to 70 years, but this is not the case in men. ${ }^{20}$

In dealing with hypertension, various solutions can be taken. However, unlike synthetic chemical drugs, the use of plants has few or no side effects. The use of natural ingredients can also be used in the treatment of hypertension. ${ }^{20}$ In this study, the natural ingredients used are Pigeon pea (Cajanus cajan) which are made in the form of adult cakes.givinggudeanasaas can reduce blood pressure in elderly women who have hypertension, both systolic and diastolic. In systolic blood pressure, the elderly who were given gudea taste for 1 month decreased by an average of $15.56 \mathrm{mmHg}$ or about $9.69 \%$. Meanwhile, the elderly who are given new feelings tend to experience an increase in systolic with an average of $0.55 \mathrm{mmHg}$ or about $0.37 \%$. In this study, it was found that the elderly who consumed the taste of Pigeon Pea $\mathrm{s}$ had a significant decrease in systolic blood pressure.

Based on diastolic pressure, the elderly who were given pigeon pea flavor for 1 month also experienced a decrease with an average of $12.23 \mathrm{mmHg}$ or about 
9.97\%. Meanwhile, the elderly who consumed ordinary foods experienced an increase in diastolic blood pressure by an average of $1.11 \mathrm{mmHg}$ or about $1.11 \%$. In this study, it was found that the elderly who consumed the taste of Pigeon Pea s experienced a significant decrease in diastolic blood pressure. This shows that the use of gude bean flour in baruasa cakes can increase the nutritional content of baruasa and provide the effect of lowering blood pressure that is expected by people with hypertension.

Pigeon Pea is one of the local foods which is quite abundant in production in the place where this research was carried out. Pigeon pea, which are made in the form of baruasa cakes, are also a form of food that is very often consumed by local people. So that there are no problems related to the acceptance of the elderly. ${ }^{21}$

The standard recipe for making gude bean flavoring can yield 700 grams of gude bean flavor (28 pieces @ 25 $\mathrm{g} / \mathrm{chip})$. Every $100 \mathrm{~g}$ of baruasa cake contains $7.37 \mathrm{mg}$ of iron, $69.76 \mathrm{~g}$ of carbohydrates, $9.58 \mathrm{~g}$ of protein, 7.75 $\mathrm{g}$ of fat, $12.6 \mathrm{~g}$ of moisture, $0.31 \mathrm{~g}$ of ash, and $4.02 \mathrm{of}$ fiber. gr (Saswini, 2015). Based on the results of research conducted by Saswini (2015), it is estimated that in 1 piece of baruasa cake with a size of $25 \mathrm{~g}$ contains about $2.4 \mathrm{~g}$ of protein. ${ }^{21}$

Pigeon pea (Cajanus cajan) are rich in amino acids, potassium, and antioxidants and are low in sodium. Pigeon pea contain sufficient amounts of essential amino acids, as well as tryptophan which is involved in the treatment of hypertension. ${ }^{22}$ Amino acids that are broken down from gude bean protein can increase insulin resistance and glucose metabolism which plays a role in lowering AGEs and oxidative stress. This results in a decrease in vascular intracellular calcium and an increase in NO synthesis which can improve endothelial function and decrease vascular resistance which then has a great opportunity to have a lowering effect on blood pressure. ${ }^{23}$ Pigeon pea also have a good balance of amino acids. Pigeon pea contain phytoestrogens that have an antiangiogenetic activity which can inhibit the formation of new blood vessels. Apart from that, Pigeon Pea s are also a good source of anti-oxidants with a fairly high phenolic content. ${ }^{21}$

Pigeon pea have also been shown to have high antioxidant activity and efficient free radical ability. ${ }^{24} \mathrm{The}$ main antioxidants in gudean nuts are mainly phenols, phenolic acids, and their derivatives, flavonoids, tools, phospholipids, amino acids, peptides, phytic acid, ascorbic acid, pigments, and sterols. Antioxidants play a big role in inhibiting free radicals and providing protection against hypertension. ${ }^{25}$ This anti-oxidant diet has been shown to lower blood pressure, there is a significant difference between systolic and diastolic blood pressure before and after giving a high antioxidant diet compared to a low antioxidant diet. Flavonoids are associated with strong antioxidant activity, inhibition of platelet aggregation, and endothelial function resulting in a decrease in blood pressure. ${ }^{16,26}$

\section{Conclusion and Recommendation}

\section{The conclusions are:}

1. There was no difference in blood pressure in advertisement with hypertension in the intervention group and the post-treatment group $(\mathrm{p}=0.077>$ $0.05)$

2. There was a difference between diastolic blood pressure and hypertension in the intervention group and the post-treatment group $(\mathrm{p}=0.000<0,05)$.

3. There was an effect of the large consumption of akacanggude(Cajanuscajan) on blood pressure in advertising systolic with hypertension $(\mathrm{p}=0.001<$ $0.05)$.

4. There was an effect of the large consumption of akacanggude(Cajanuscajan) on diastolic blood pressure with hypertension $(\mathrm{p}=0.001<0,05)$.

\section{The recommendations are:}

1. Eat new cakes of Pigeon pea that are rich in nutritional content to lower blood pressure.

2. Make gudea fresh taste as a side cake to be consumed during a distraction because it's easy to make and can be stored for a long time.

3. For future researchers, it is possible to:

4. To examine the effect of gudean taste on blood pressure in elderly men with hypertension.

5. Researching the length of time to store the Gude Bean Baurasa cake (expired date

Source of Funding: Author

Conflict of Interest: No

Ethical Clearence: Yes 


\section{References}

1. Mobbs C. The merck manual of geriatric, Section 1, Chapter 1, Biology of aging. Merck.2006 [cited 29 December 2019]. Available from: http://www. merck.com/pubs/mm_geriatrics/sec1/ch1.html.

2. Kemenkes RI. Riset Kesehatan Dasar. Jakarta: Badan Penelitian dan Pengembangan Kesehatan; 2013.

3. Wahdah, N. Menaklukan Hipertensi dan Diabetes. Yogyakarta: Penerbit Multipres; 2011

4. Hartono, B. Hipertensi; the Silent Killer. Hari Hipertensi Sedunia. Jakarta: Perhimpunan Hipertensi Indonesia; 2011.

5. Chinnakali, P., Mohan, B., Upadhyay, R. P., Singh, A. K., Srivastava, R. \& Yadav, K. Hypertension in the Elderly: Prevalence and Health Seeking Behavior. N Am J Med Sci. 2012: 4, 558-62.

6. WHO (World Health Organization). A global brief on hypertension: silent killer, global public health crisis. World Health Day. Report, 1-39. Geneva, Switzerland: World Health Organization;2013.

7. Vasan RS, Larson MG, Leip EP, Evans JC, O’Donnell CJ, Kannel WB, Levy D. Impact of highnormal blood pressure on the risk of cardiovascular disease. N Engl J Med.2001; 345: 1291-1297. doi: 10.1056/NEJMoa003417.

8. Ried, K. \& Fakler, P. Potential of Garlic (Allium Sativum) in Lowering High Blood Pressure: Mechanisms of Action and Clinical Relevance. Integr Blood Press Control, 2014; 7, 71-82.

9. Bangalore S, Messerli FH, Wun CC, et al. J-curve revisited: an analysisof blood pressure and cardiovascular events in the Treating to NewTargets (TNT) Trial. Eur Heart J.2013;31(23):2897-2908.

10. Djibril M. Satu dari Tiga Orang Indonesia Menderita Hipertensi.ROL.2014.[cited 29 December 2019]. Available from:http://www.republika.co.id/berita/ gaya- hidup/info sehat/13/04/05/mkqsbs-satu-daritiga-orang-indonesia-menderita hipertensi

11. Dinkes Jeneponto.Profil Kesehatan Kabupaten Jeneponto Tahun 2014. Jeneponto, Dinas Kesehatan Kabupaten Jeneponto; 2015.

12. Puskesmas Barana. 2016. Profil Puskesmas Barana. Jeneponto, Dinas Kesehatan Kabupaten Jeneponto.

13. Nueva, S. A Cross-Sectional Study Examining the Need for Nutrition Intervention and the Presence of Malnutrition in A Community in Rural
Guatemala,2013

14. Mollik, M. Investigations of Plants Used For The Hypertension In The Daganbhuiyan Upazila Within Feni District Of Bangladesh; 2012.

15. Lawal, O.U. The mineral and phytochemical analysis of leaves of Senna alata and Cajanus cajan and their medicinal value. International Journal of Biology, Pharmacy and Allied Science.2012; 1:111.

16. Liputo, N.I., Rosalina, L. \& Sulastri, D.. Pemberian Diet Minagkabau Tinggi Sumber Anti-Oksidan dapat Menurunkan Tekanan Darah. Padang: Universitas Andalas; 2008.

17. Wolff, HP. Your Health Guide: Speaking of High Blood Pressure. A Comprehensive Guide for Hypertensives and their Partners. First Indian Edition. New Delhi: Sterling Publishers Private Liited; 2008.

18. Lima, R., M. Wofford \& J. F. Reckelhoff. Hypertension in Postmenopausal Women. Current Hypertension Reports. 2012; 14(3): 254-260.

19. Fernandez VF, Abellan J, Vegazo O, De Vinuesa SG, Rodriguez JC, Maceira B, de Castro SS, Nicolas RR, \& Luno J. Angiotensin II type 1 receptor blockade to control BP in postmenopausal women: influence of hormone replacement therapy. Kidney Int.2002; (Suppl):S36-S41.

20. Mansego ML, Redon J, Marin R, González-Albert V, Martin-Escudero JC, Fabia MJ, Martinez F, \& Chaves FJ. Renin polymorphisms and haplotypes are associated with BP levels and hypertension risk in postmenopausal women. J Hypertension.2008; 26:230-237.

21. Kunia, K. Potensi Kacang Hiris untuk Obat dan Pangan. 2008. [cited 29 December 2019]. Available from: http://kabelankunia.com/2008/11/potensikacang-hiris-untuk-obat-dan.html/

22. Aiyeloja, A.A. \& Bello, OA. Ethno-botanical potentials of common herbs in Nigeria: A case study of Enugu state. Educational Review. 2006;1: 16-22.

23. Vasdev, S. \& J. Stuckless. "Antihypertensive effects of dietary protein and its mechanism." The International Journal of Angiology : Official Publication of the International College of Angiology, Inc. 2010; 19(1): e7-e20.

24. Wu, N., K. Fu, Y. J. Fu, Y. G. Zu, F. R. Chang, Y. H. Chen, X. L. Liu, Y. Kong, W. Liu \& C. B. 
Gu. Antioxidant activities of extracts and main components of Pigeonpea [Cajanus cajan (L.) Millsp.] leaves. Molecules 14(3): 1032-1043.

25. Ahmad, S.V., Shah, F.H. \& M.S. Chaudry. 2008. Effect of cooking on the essential amino acids content and net protein utilization (NPU) of common pulses. Pakistan. Journal of Science and Industrial Research.2009; 18(3-4): 175-178

26. Naseri, M.K., Arabian, M., Badavi, M. \& Ahangarpour, A. Vasorelaxant and hypotensive effects of Allium cepa peel hydroalcoholic extract in rat. Pak J Biol Sci, 2008; 11: 1569-75. 